\title{
Sociodemographic and Clinical Characteristics of Psychiatric Re-hospitalizations
}

\author{
Sueli Aparecida de Castro ${ }^{1}$ \\ Antonia Regina Ferreira Furegato ${ }^{2}$ \\ Jair Licio Ferreira Santos ${ }^{3}$
}

\begin{abstract}
Segregated individuals with mental disorders, families without support or guidance concerning disease and treatment, and unprepared professionals are some of the factors that can contribute to re-hospitalizations. This study identifies sociodemographic variables, clinical conditions, diagnoses and treatments in order to identify their relationship with psychiatric re-hospitalizations. This is an exploratory and descriptive study. A form was used to search data in patients' files from 2006 and 2007 in a regional psychiatric facility. A total of 681 re-hospitalizations were identified, the majority due to treatment abandonment. Length of hospitalization was higher for women between 40 and 49 years of age. Positive associations of sociodemographic data with previous hospitalizations were found, such as type of discharge, and physical and mental condition, which is in accordance with the literature. Readmissions are associated with sociodemographic and clinical indicators. These findings can guide care and public policies regarding mental health.
\end{abstract}

Descriptors: Hospitalization; Psychiatry; Psychiatric Nursing; Mental Health.

\footnotetext{
${ }^{1}$ RN, Hospital Psiquiátrico Santa Tereza de Ribeirão Preto. Master's Student in Nursing, Escola de Enfermagem de Ribeirão Preto, Universidade de São Paulo, WHO Collaborating Centre for Nursing Research Development, SP, Brazil. E-mail: castrossueli@hotmail.com.

${ }^{2}$ RN, Ph.D. in Nursing, Full Professor, Escola de Enfermagem de Ribeirão Preto, Universidade de São Paulo, WHO Collaborating Centre for Nursing Research Development, SP, Brazil. E-mail: furegato@eerp.usp.br.

${ }^{3}$ Physicist, Ph.D. in Public Health, Full Professor, Faculdade de Medicina de Ribeirão Preto, Universidade de São Paulo, SP, Brazil. E-mail: jalifesa@usp.br.
}

Corresponding Author:

Antonia Regina Ferreira Furegato

Universidade de São Paulo. Escola de Enfermagem de Ribeirão Preto

Av. Bandeirantes, 3900

Bairro Monte Alegre

CEP: 14040-902 Ribeirão Preto, SP, Brasil

E-mail: furegato@eerp.usp.br 


\title{
Características sociodemográficas e clínicas em reinternações psiquiátricas
}

Portadores de transtorno mental discriminados, famílias sem apoio e orientação sobre a doença e tratamentos e profissionais despreparados são alguns dos fatores que podem contribuir para as reinternações. O objetivo deste estudo foi identificar as variáveis sociodemográficas, as condições clínicas, o diagnóstico médico e tratamento, buscando sua relação com as reinternações psiquiátricas. A metodologia usada aqui foi exploratóriodescritiva. Utilizou-se roteiro para levantamento dos dados nos prontuários, de 2006 e 2007, num hospital psiquiátrico regional. Foram encontradas 681 reinternações, a maioria por abandono de tratamento. O tempo de permanência na internação é maior nas mulheres de 40 a 49 anos. Este estudo mostrou, também, associações positivas dos dados sociodemográficos com internações anteriores, tipo de alta, estado físico e mental, os quais estão de acordo com outros dados da literatura. Conclui-se que há associações das reinternações com indicadores sociodemográficos e clínicos que podem direcionar o cuidado e políticas públicas na saúde mental.

Descritores: Hospitalização; Psiquiatria; Enfermagem Psiquiátrica; Saúde Mental.

\section{Caracterización sociodemográfica y clínica de reinternaciones psiquiátricas}

\begin{abstract}
Algunos de los factores que pueden contribuir para las reinternaciones psiquiátricas son los trastornos mentales que ocurren en familias sin apoyo u orientación acerca de la enfermedad y tratamientos y, por causa de profesionales mal preparados. El objetivo de este estudio fue identificar las variables sociodemográficos, las condiciones clínicas, los diagnósticos médicos, los tratamientos y su relación con las reinternaciones psiquiátricas. Se trata de un estudio exploratorio y descriptivo, en el cual se utilizó un guía para recolectar datos en los registros médicos de 2006 y 2007, en un hospital psiquiátrico regional. Fueron identificadas 681 reinternaciones, la mayoría por abandono de tratamiento. El tiempo de permanencia en la internación fue mayor para la mujeres que tenían de 40 a 49 años. Se encontró asociaciones positivas de los datos sociodemográficos con internaciones anteriores, tipo de alta, estado físico y mental, los cuales están de acuerdo con otros datos de la literatura. Se concluye que las reinternaciones están asociadas con indicadores sociodemográficos y clínicos; conocimiento que puede ser utilizado en las políticas públicas en salud mental sobre el cuidado.
\end{abstract}

Descriptores: Hospitalización; Psiquiatría; Enfermería Psiquiátrica; Salud Mental.

\section{Introduction}

The movement to reorient the Brazilian care model for mental health has been extensively discussed and defended. In practice, however, the guidelines of psychiatric reform and advancements in science have not guided practice. Although the quantity of services has significantly increased, re-hospitalizations have also grown considerably and the average duration of hospitalizations is longer, while intervals between readmissions of a relative large number of patients are small(1-4). The quantity of outpatients' visits does not necessarily mean effective resolution. Many of these services are not very efficient, generate demand and contribute to conditions to become chronic (5), consequently leading to re-hospitalizations.

When a medical diagnosis is defined in psychiatric care, it guides the therapeutic plan of patients with mental disorders, which includes pharmacological, social and psychological interventions and nursing care. 
Concomitantly, emerging family conflicts, guilt, social isolation, lack of knowledge concerning the disease and difficulties in coping with a situation that results from financial overload and difficulty in interpersonal relationships should be detected ${ }^{(6-7)}$.

Integration between the health system and families should occur when the first manifestations of the mental disorder start, in order to avoid rupturing the relationships between the individual with a mental disorder with his/her family and the community. Many families and even individuals with mental disorders believe that hospitalization is still the best treatment

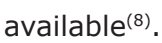

Taking these factors into account, we conclude that psychiatric hospitalization may reflect the clinical conditions of patients and also the support provided by families and the community and the efficiency of the psychiatric facilities. These are, in a certain way, an epidemiological warning and indicate the need to initiate appropriate follow-up strategies that are integrated between the sectors involved instead of isolated measures ${ }^{(4-5,9)}$.

The decision-making power of patients with mental disorders is limited during hospitalization and all their actions are controlled according to the facilities' standards, where there is not always a concern for each individual's uniqueness nor for family members ${ }^{(10)}$. Extrahospital services, in turn, perhaps do not have conditions to widely examine the issue of exclusion and care for individuals in crisis, as is the case of Psychosocial Care Centers (CAPS) and psychiatric emergency departments in general hospitals ${ }^{(11-13)}$.

From the perspective of care coverage, the majority of community services have limited coverage, especially for patients with more severe and chronic clinical conditions. Hence, the responsibility to care for these patients in the daily routine lies with the families ${ }^{(6-7,14)}$.

Therefore, appropriate treatment implies the rational use of hospitalization, consisting of pharmacological, psychological and social interventions, which should be clinically significant, balanced and integrated with better quality care ${ }^{(15)}$. This perception of illness eliminates the reductionist view of mental problems and aggregates biopsychosocial factors and new ways of addressing, treating and organizing the psychiatric care network.

A higher incidence of readmissions has been observed in a hospitalization unit for acute female patients of a psychiatric facility. We observe that patients are readmitted not only because of clinical relapses but also due to a lack of family and social support, lack of adherence to treatment or abandonment of treatment, lack of medication available in the network and even interruption of treatment due to the lack of physicians and lack of knowledge concerning the particular disease and treatment.

These observations justify the analysis of some characteristics of individuals with mental disorders and relate them to readmissions with a view to present data to support more effective care both in closed facilities and the entire community health care network in order to reduce the frequency of psychiatric hospitalizations.

This study identifies sociodemographic variables, clinical conditions, medical diagnoses and treatments and analyzes their relationship with psychiatric readmissions.

\section{Method}

\section{Study design}

This study uses an exploratory-descriptive methodology based on secondary data: information contained in the medical files of patients hospitalized in a psychiatric hospital between 2006 and 2007.

\section{Study's setting}

The psychiatric Hospital Santa Teresa de Ribeirão Preto (HST-RP) currently has the following sectors: Acute Female, Acute Male, Chemical Dependents and Permanent Residents. Its mission is to provide humanized and individualized care to patients 16 years old or older, belonging to the XIII Regional Health Department (DRS XIII), with mental disorders and who present imminent risk to themselves and others. It also aims to re-insert permanent residents into the community and family life(16).

\section{Sampling and data collection procedures}

Data were collected from the Medical Records Services (SAME) at the HST-RP. A daily census was used to select patients' files. The files of patients hospitalized for the first time were excluded.

Readmissions between January 2006 and December 2007 were verified in the annual report concerning the movement of patients. The reference used in the sample was the last hospitalization; the total number of readmissions or whether the patient was hospitalized at the time of this study was not taken into account.

\section{Data collection instrument}

A form was used to guide data collection from patients' files: "Survey of Psychiatric Readmissions" 
- SPR. This instrument included sociodemographic and clinical data obtained from the Hospitalization Authorization form, found in the Record of Hospital Discharge from the last hospitalization and others found in previous hospitalizations: 1- Identification of individuals (age, gender, ethnicity, education, place of birth and marital status); 2- Clinical information at admission (reason for hospitalization, physical and mental conditions, previous hospitalizations, disease onset and medical diagnosis) and hospital discharge (type and treatment provided during hospitalization, physical and mental conditions, diagnosis, medication scheme and therapeutic proposal).

\section{Ethical Procedures}

The project was approved by the Ethics Research Committee at the University of São Paulo at Ribeirão Preto, College of Nursing, according to CEP 196/96. Because this study was carried out with secondary data, the use of a written consent form was not required (protocol 0829/2007). The Research Committee at the HST-RP authorized the procedure and scientific dissemination of data in August 2007.

\section{Analysis procedures}

Information was recorded and individuals were identified by a numerical code. Data were analyzed through descriptive analysis seeking correlations between variables, associating readmissions with gender, age groups and clinical conditions upon admission and discharge. The analysis of clinical conditions was carried out through the comparison of clinical assessment upon admission and hospital discharge. Diagnoses upon admission and hospital discharge were grouped according to ICD-10. Treatments provided were grouped according to information contained in the Hospital Discharge Record.

Fisher's Exact Test, Pearson's Chi-square and $\mathrm{t}$ - test for means were computed in STATA software, version 10.0. Discussion was supported by literature addressing the theme.

\section{Results}

Based on analysis of data obtained in this study and despite blanks found in the consulted documents, it was possible to make associations between psychiatric readmissions and patients' sociodemographic variables and clinical conditions upon admission and hospital discharge, medical diagnoses and treatments provided.

\section{Sociodemographic variables and psychiatric readmissions}

A total of 2,040 hospitalizations were identified between January 2006 and December 2007 in the HST$\mathrm{RP}$, of which 681 (34\%) correspond to readmissions.

Table 1 - Readmissions of patients in the Hospital Santa Tereza de Ribeirão Preto from January $1^{\text {st }} 2006$ to December $31^{\text {st }} 2007$, according to region, place of birth and gender.

\begin{tabular}{|c|c|c|c|c|c|c|c|}
\hline \multirow{2}{*}{ Regions } & \multirow{2}{*}{ States } & \multicolumn{2}{|c|}{ Male } & \multicolumn{2}{|c|}{ Female } & \multicolumn{2}{|c|}{ Total } \\
\hline & & $\mathrm{N}^{\circ}$ & $\%$ & $\mathbf{N}^{\circ}$ & $\%$ & $\mathrm{~N}^{\circ}$ & $\%$ \\
\hline \multirow[t]{4}{*}{ Southeast } & Minas Gerais & 44 & 10 & 27 & 10 & 71 & 10 \\
\hline & São Paulo & 274 & 65 & 163 & 63 & 437 & 64 \\
\hline & Espírito Santo & 1 & & & & 1 & \\
\hline & Rio de Janeiro & 1 & & & & 1 & \\
\hline \multirow[t]{3}{*}{ South } & Santa Catarina & 1 & & & & 1 & \\
\hline & Paraná & 11 & 3 & 11 & 4 & 22 & 3 \\
\hline & Rio Grande do Sul & 2 & & & & 2 & \\
\hline \multirow[t]{6}{*}{ Northeast } & Piauí & 1 & & 1 & & 2 & \\
\hline & Bahia & 13 & 3 & 7 & 3 & 20 & 3 \\
\hline & Maranhão & & & 1 & & 1 & \\
\hline & Ceará & 1 & & & & 1 & \\
\hline & Paraíba & 1 & & 1 & & 2 & \\
\hline & Alagoas & 1 & & & & 1 & \\
\hline \multirow[t]{2}{*}{ Midwest } & Goiás & 3 & 1 & 3 & 1 & 6 & 1 \\
\hline & Mato Grosso & 1 & & 2 & 1 & 3 & 1 \\
\hline Not available & & 67 & 16 & 43 & 17 & 110 & 16 \\
\hline Total & & 422 & 62 & 259 & 38 & 681 & 100 \\
\hline
\end{tabular}


Of the 681 readmitted individuals, 30\% were between 40 and 49 years old. A significant difference was found between the frequencies of individuals in age groups according to gender (Fisher's test=0.007).

Among the 627 files where information was provided regarding race, we observed that $66 \%$ were white, $10 \%$ black and $16 \%$ mixed. The level of schooling recorded in $67 \%$ of files revealed that $8 \%$ were illiterate; 157 men (38\%) and 156 women (59\%) did not complete primary school; 34 men ( $8 \%)$ and 44 women $(16 \%)$ began secondary school but only 21 (5\%) and $30(11 \%)$ respectively concluded it. Six men and seven women began higher education but only three acquired a bachelor's degree.

It was possible to observe in the files that recorded marital status that the number of singles who were readmitted was higher among men (66\%) than among women (45\%). There were more widowed (16) and separated (38) women than men in these conditions.

The Chi-square test showed a significant result $(P=0.000)$ in the comparison between gender and schooling indicating that women readmitted had more years of schooling than men. A significant difference was found in the association between marital status and gender; most of the readmitted men were single (Fisher=0.000).
Table 2 - Distribution of readmissions in the Hospital Santa Tereza de Ribeirão Preto by age group and gender in 2006 and 2007.

\begin{tabular}{|c|c|c|c|c|}
\hline \multirow{3}{*}{ Age range } & \multicolumn{2}{|c|}{ Gender } & \multirow{2}{*}{\multicolumn{2}{|c|}{ Total }} \\
\hline & \multirow{2}{*}{$\begin{array}{c}\text { Male } \\
\mathrm{N}^{\circ}\end{array}$} & \multirow{2}{*}{$\begin{array}{c}\text { Female } \\
\mathrm{N}^{\circ}\end{array}$} & & \\
\hline & & & $\mathrm{N}^{\circ}$ & $\%$ \\
\hline 16 to 29 & 133 & 54 & 187 & 27 \\
\hline 30 to 39 & 96 & 58 & 154 & 23 \\
\hline 40 to 49 & 112 & 90 & 202 & 30 \\
\hline 50 and older & 73 & 60 & 133 & 19 \\
\hline Not recorded & 04 & 01 & 05 & 1 \\
\hline Total & 418 & 263 & 681 & 100 \\
\hline
\end{tabular}

\section{Patients'clinical conditions, diagnoses and treatments associated with psychiatric readmissions}

The Chi-square test evidenced a significant result in the comparison between hospitalization and gender $\left(X^{2}=0.002\right)$. The number of patients without previous hospitalizations for psychiatric treatment decreases as age increases; a higher proportion of men is observed (Fisher=0.003).

Differences between type of discharge and age were also observed. The highest proportion of medical discharge occurred between 40 and 49 years (95\%) and the lowest between 16 and 29 years old (90\%). Medical discharge occurred more frequently among the oldest patients and against-medical-advice-discharge among the youngest ones $\left(X^{2}=0.003\right)$.

Table 3 -Motives of readmissions between 2006 and 2007 in the Hospital Santa Tereza de Ribeirão Preto according to age groups

\begin{tabular}{|c|c|c|c|c|c|c|c|c|c|c|c|c|}
\hline \multirow{3}{*}{ Motives for the last hospitalization } & \multicolumn{10}{|c|}{ Age Groups } & \multirow{2}{*}{\multicolumn{2}{|c|}{ Total }} \\
\hline & \multicolumn{2}{|c|}{16 to 29} & \multicolumn{2}{|c|}{30 to 39} & \multicolumn{2}{|c|}{40 to 49} & \multicolumn{2}{|c|}{50 old or older } & \multicolumn{2}{|c|}{ Not recorded } & & \\
\hline & $\mathbf{N}^{\circ}$ & $\%$ & $\mathbf{N}^{\circ}$ & $\%$ & $\mathbf{N}^{\circ}$ & $\%$ & $\mathbf{N}^{\circ}$ & $\%$ & $\mathbf{N}^{\circ}$ & $\%$ & $\mathbf{N}^{\circ}$ & $\%$ \\
\hline Treatment abandonment & 98 & 52 & 69 & 47 & 96 & 47 & 57 & 43 & 3 & 60 & 323 & 47 \\
\hline Improvement in health conditions & 3 & 2 & 2 & 1 & 4 & 2 & 1 & 1 & & & 10 & 1 \\
\hline Lack of physician in the network & & & & & 1 & 1 & & & & & 1 & 1 \\
\hline Lack of family support & 8 & 4 & 4 & 3 & 7 & 3 & 8 & 6 & & & 27 & 4 \\
\hline Failures in the treatment & 32 & 17 & 32 & 21 & 43 & 21 & 35 & 26 & 1 & 20 & 143 & 21 \\
\hline Family support + Abandonment & 39 & 21 & 40 & 26 & 34 & 17 & 20 & 15 & & & 133 & 19 \\
\hline Failures in the treatment + Abandonment & & & 1 & 1 & & & & & & & 1 & 1 \\
\hline Failures in the treatment + Family support & 2 & 1 & & & 7 & 3 & 7 & 5 & & & 16 & 2 \\
\hline Not recorded & 5 & 3 & 6 & 4 & 10 & 5 & 5 & 4 & 1 & 20 & 27 & 4 \\
\hline Total & 187 & 100 & 154 & 100 & 202 & 100 & 133 & 100 & 05 & 100 & 681 & 100 \\
\hline
\end{tabular}

Among the diagnoses recorded upon readmission, the highest prevalence was of schizophrenic disorders $(27 \%)$, followed by bipolar affective disorders (23\%) and mental and behavioral disorders due to alcohol and drug use (12\%). The diagnoses prevalent upon discharge were schizophrenic disorders (26\%), followed by bipolar affective disorders (22\%) and mental and behavioral disorders due to alcohol and drugs $(10 \%)$, which correspond to those recorded upon readmission.

The age of onset of the disease is higher in men than in women. The $\mathrm{t}$ - test for means revealed a 
significant result in the age group from 30 to 39 years old $(P=0.0011)$. Average duration of hospitalization is higher for women $(34.5 \%)$, especially for those between 40 and 49 years of age $(P=0.032)$.

Table 4 - Frequency of readmissions of patients in the Hospital Santa Tereza de Ribeirão Preto according to mental condition upon admission and hospital discharge between January 2006 and December 2007.

\begin{tabular}{|c|c|c|c|c|c|c|c|c|c|c|c|c|c|}
\hline \multirow{3}{*}{$\begin{array}{l}\text { Mental condition } \\
\text { upon admission }\end{array}$} & \multicolumn{12}{|c|}{ Mental condition upon discharge } & \multirow{3}{*}{$\begin{array}{l}\text { Total } \\
\mathbf{N}^{\circ}\end{array}$} \\
\hline & \multicolumn{2}{|c|}{ Calm } & \multicolumn{2}{|c|}{ Agitated } & \multicolumn{2}{|c|}{ Depressed } & \multicolumn{2}{|c|}{ Delirious } & \multicolumn{2}{|c|}{ Others } & \multicolumn{2}{|c|}{ Not informed } & \\
\hline & $\mathbf{N}^{\circ}$ & $\%$ & $\mathbf{N}^{\circ}$ & $\%$ & $\mathbf{N}^{\circ}$ & $\%$ & $\mathbf{N}^{\circ}$ & $\%$ & $\mathbf{N}^{\circ}$ & $\%$ & $\mathbf{N}^{\circ}$ & $\%$ & \\
\hline Calm & 122 & 85 & & & 1 & 1 & 5 & 3 & 6 & 4 & 10 & 7 & 144 \\
\hline Agitated & 49 & 79 & 1 & 2 & & & & & 7 & 11 & 5 & 8 & 62 \\
\hline Depressed & 66 & 85 & 1 & 1 & 3 & 4 & & & 4 & 5 & 4 & 5 & 78 \\
\hline Delirious & 226 & 74 & 2 & 1 & 7 & 2 & 35 & 11 & 19 & 6 & 17 & 6 & 306 \\
\hline Others & 68 & 87 & 1 & 1 & & & 2 & 3 & 5 & 6 & 2 & 3 & 78 \\
\hline Not informed & 9 & 69 & & & & & 1 & 8 & 2 & 15 & 1 & 8 & 13 \\
\hline Total & 540 & 79 & 5 & 1 & 11 & 2 & 43 & 6 & 43 & 6 & 39 & 6 & 681 \\
\hline
\end{tabular}

In analyzing readmissions considering physical condition upon admission in relation to gender, we observed that women are in better condition than men (Fisher=0.004). A significant result was found in the comparison of physical condition reported upon discharge both to gender (Fisher=0.037) and age (Pearson=0.004).
Significant differences were observed in relation to mental heath in the comparison of age groups $(\mathrm{P}=0.007)$; young and old patients present the lowest percentage of calm individuals, while those in the age group 30 to 50 years old were the calmest ones only upon discharge.

Table 5 - Distribution of readmissions in the Hospital Santa Tereza de Ribeirão Preto according to patients' gender and type of treatment provided during hospitalization

\begin{tabular}{|c|c|c|c|c|}
\hline \multirow{2}{*}{ Treatment provided } & \multicolumn{2}{|c|}{ Gender } & \multicolumn{2}{|c|}{ Total } \\
\hline & Male & Female & $\mathbf{N}^{\circ}$ & $\%$ \\
\hline Pharmacological & 76 & 90 & 166 & 24 \\
\hline Pharmacological +Psychological & 205 & 88 & 293 & 43 \\
\hline Pharmacological + Occupational Therapy & 5 & 7 & 12 & 2 \\
\hline Pharmacological + Family Therapy & 12 & 12 & 24 & 4 \\
\hline Pharmacological + Therapeutic plan & 1 & 6 & 7 & 1 \\
\hline Psychological + Pharmacological + Occupational Therapy & 74 & 23 & 97 & 14 \\
\hline Psychological + Pharmacological + Therapeutic plan & 16 & 8 & 24 & 4 \\
\hline Family Therapy + Occupational Therapy + Pharmacological & 1 & & 1 & \\
\hline Therapeutic plan + Psychological + Pharmacological & 2 & 9 & 11 & 2 \\
\hline Therapeutic plan + Occupational Therapy + Pharmacological & & 1 & 1 & \\
\hline Therapeutic plan + Family Therapy + Pharmacological & & 2 & 2 & \\
\hline All & 5 & 6 & 11 & 2 \\
\hline Not recorded & 21 & 11 & 32 & 5 \\
\hline Total & 418 & 263 & 681 & 100 \\
\hline
\end{tabular}

Most of the patients received pharmacological treatment associated with psychological treatment (293). In cross-referencing information of hospitalized patients' treatments and age groups we found that pharmacological treatment more frequently occurs among individuals (53) between 40 and 49 years old.

\section{Discussion}

Overall, the results correspond to those found in the psychiatric literature, especially to those of an epidemiological study carried out in Ribeirão Preto, SP,

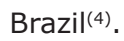


Information concerning place of birth (571) was found in patients' files and three quarters were born in the Southeast region, predominately individuals from the state of São Paulo followed by Minas Gerais. There is a predominance of men in all regions. Most of the readmissions originate from cities in the DRS XIII, which complies with the principles of regionalization and hierarchy according to law no $8.080^{(16)}$.

The city of Ribeirão Preto accounted for the majority of readmissions, followed by Sertãozinho and Jaboticabal, SP. Ribeirão Preto currently has 504,923 inhabitants and despite the fact it is the center of the region, it still is deficient in community services( ${ }^{(17)}$. In this respect, it is worth questioning whether neighboring cities are assuming the mental health care as recommended by psychiatric reform. The deficiency of these services can hinder integration of services, so necessary to psychosocial rehabilitation, which allow people functional psychiatric recovery ${ }^{(13-14,18)}$

Among the reasons that determined the last hospitalization in the different age groups, the youngest individuals who abandoned treatment (98) and those between 40 and 49 years of age (96) stood out. Poor family support associated with treatment abandonment is more frequent among young individuals and those between 30 and 39 years of age. Failures in treatment were more frequent among those between 40 and 49 years of age (43).

Men presented a higher proportion of readmissions due to treatment abandonment (216) than women (107), which was associated with poor family support in 85 men and 48 women. A large number of patients who did not take the prescribed medication were observed. It is known that failures in treatment are important causes of relapse, as observed in this study. A consequence of interrupted psychiatric treatment is the risk of relapse with a negative impact on the patients' balance and disease overload on the family(6-7,9).

We verified in this study that three patients had psychiatric hospitalization mandated by court. These cases have increased. The facility received 26 patients from January to September 2007 mandated by a court $\operatorname{order}^{(17)}$. This demand interferes with the true reason of hospitalization (medical evaluation) and also destabilizes the structure and dynamics of inpatient units.

In relation to disease onset, a larger number of young male individuals between 16 and 29 years of age $(P=0.007)$ was observed. It might be a consequence of the prevalence of schizophrenic and mood disorders, and drug use, which are manifested more frequently among adolescents and young individuals.
A total of 461 out of the 681 individuals were previously hospitalized in this facility from one to four times; 193 were hospitalized only once; 130 individuals were hospitalized from five to nine times, with a higher frequency among individuals between 40 and 49 years of age. We clearly observed that the younger the individuals the less frequent were hospitalizations.

Hospitalizations in another hospital occurred in the majority of cases (4/5 ths of total). Hospitalizations in another hospital were more frequent among people between 40 and 49 years of age and among the youngest individuals.

The observed duration of hospitalization may have been influenced by multiple factors such as diagnosis, clinical condition, age, gender, economic situation, family and social support, adherence to community service, residual symptoms and social skills ${ }^{(9,14)}$.

Concerning the manifestation of mental symptoms upon admission and hospital discharge, calm patients stood out and $85 \%$ remained so upon discharge; among the agitated ones upon admission, 79\% were calm upon discharge and $11 \%$ were delirious upon discharge. Women presented better physical conditions at discharge.

Most of the time an individual with a mental disorder needs to be hospitalized in order to have his/her clinical condition stabilized due to symptoms such as delusions, hallucinations, agitation or speech disorders and suicidal thoughts or even to meet the needs of families with relational difficulties and emotional overload(4,6,8,15,19).

This study revealed that most of the mental conditions justified hospitalization due to the presence of such symptoms. However, many patients were calm upon hospitalization, a condition not covered by Law 10.216, although many patients originated from the Emergency Department of the Hospital das Clinicas and the acute condition upon admission might have been less symptomatic.

Pharmacological treatment accompanied by psychological treatment was prescribed for a larger number of patients (95) between 40 and 49 years of age. Pharmacological treatment and family therapy is restricted as observed in the different psychiatric services $^{(13)}$.

Despite the existence of nursing notes taken daily in all periods, we observed that nursing care is not considered a treatment nor are social interventions, evidencing that in daily practice, the treatment considered is medication.

Law 10.216 recommends access to better treatment, in line with the needs of individuals with mental 
disorders, including medical and nursing services, social work, psychological and occupational care, and leisure among others ${ }^{(1,5,11,14)}$.

Non-physicians need to better define their role in the care provided to patients with mental disorders and find appropriate strategies for interventions to justify the importance of their contribution to psychiatric care.

The nursing team has the opportunity to detect needs presented by patients with mental disorders under its care during the entire period of care delivery. Through different technical care procedures and personal interactions, nurses can help hospitalized patients to better understand their disease, treatments and utilize other psychosocial resources, enabling patients to become active participants in the process ${ }^{(20)}$.

The frequency and duration of psychiatric hospitalizations is still a concern due to social exclusion and personal loss that it causes. A recent study carried out in Brazil with 307 adults with a history of three or more hospitalizations and a control group of 354 individuals hospitalized for the first time showed that psychosocial variables play an important role in the prevention of multiple readmissions ${ }^{(19)}$.

The psychiatric nurse, as a member of multiprofessional teams, needs to advance within the mechanisms that promote changes in practices through the aggregation of new knowledge and competencies.

\section{Conclusions}

This study describes sociodemographic and clinical characteristics of patients readmitted in the Hospital Santa Tereza de Ribeirão Preto between 2006 and 2007, revealing that the population that uses this service within the Single Health Service (SUS) has social, economic and medical care needs. Such a statement can contribute to improving interventions performed with individuals with mental disorders, and help them to overcome the challenge of living with a mental disease and develop new social roles.

This study revealed that most of the re-hospitalized individuals originated from Ribeirão Preto and were readmitted due to treatment abandonment, while the largest part of the clientele had already been hospitalized in another psychiatric facility. This data strengthens the view that there is poor family and social support, lack of bonds with community services that provide superficial work, and probably without individual therapeutic projects.

This study confirmed that the flow of care is in agreement with the SUS principles of regionalization and hierarchy. Patients with mental disorders are hospitalized only with a referral from the network of services in the city and cities from the DRS XIII, where there is a structured mental health team available.

The study also revealed there is a positive relationship between readmissions and age, schooling, marital status, motive of hospitalization, type of diagnosis, previous hospitalizations in another psychiatric facility, type of discharge, treatment, and physical and mental condition upon admission and discharge.

These results can help to improve the work of professionals in mental health services and encourage active participation of patients with mental disorders and their family members in their treatment, consequently preventing readmissions. It is also a clear indicator of the need for decentralized and efficient mental health services.

\section{References}

1. Ministério da Saúde (BR). Secretaria de Atenção à Saúde. Departamento de Ações Programáticas e Estratégicas. Saúde mental no SUS: acesso ao tratamento e mudança do modelo de atenção. Relatório de gestão 2003-2006. Brasília; 2007.

2. Ministério da Saúde Secretaria Executiva (BR). Informações de Saúde - DATASUS. Tecnologia da informática a serviço do SUS. 2004. [Acesso 16 junho 2009]. Disponível em: http:// w3.datasus.gov.br/tabnet/tabnet.php.

3. Mello R, Furegato ARF. Internações psiquiátricas no Rio de Janeiro de 1996 a 2005. Rev Enferm UERJ. 2007;15(2):176-82.

4. Santos R. Estudo das reinternações psiquiátricas na região de Ribeirão Preto no período de 1998-1999. [Dissertação Mestrado]. Ribeirão Preto: Faculdade de Medicina de Ribeirão Preto/USP; 2003.

5. Lancamn S. Instituições psiquiátricas e comunidades: um estudo de demanda em saúde mental no Estado de São Paulo, Brasil. Cad Saúde Pública. 1997;13(1):93-102.
6. Koga M, Furegato ARF. Convivência com a pessoa esquizofrênica: sobrecarga familiar. Ciênc Cuidado Saúde. 2002;1(1):5-9.

7. Borba LD, Schwartz E, Kantorski LR. A sobrecarga da família que convive com a realidade do transtorno mental. Acta Paul Enferm. 2008; 21(4):558-94.

8. Salles MM, Barros S. Reinternação em hospital psiquiátrico: a compreensão do processo saúde/doença na vivência do cotidiano. Rev Esc Enferm USP. 2007; 41(1):73-81.

9. Silva NC, Bassani DG, Palazzo LS. A case-control study of factors associated with multiple psychiatric readmissions. Psychol Serv. 2009;60:786-91.

10. Vianna PCM, Barros S, Martins ASS. O modelo assistencial em saúde mental: visão de familiares. Rev Min Enferm. 2004;8(3):374-81 
11. Ministério da Saúde (BR). Secretaria Executiva. Legislação em saúde mental 1990-2004. 5. ed. Brasília (DF); 2004.

12. Soares SRR, Saeki T. O Centro de atenção psicossocial sob a ótica dos usuários. Rev. Latino-Am. Enfermagem. 2006; 14(6): 923-9.

13. Osinaga LM, Furegato ARF, Santos JLF. Users of three psychiatric services: profile and opinion. Rev. Latino-Am. Enfermagem. 2007; 15(1):70-7.

14. Gonçalves, AM; Sena RR. A reforma psiquiátrica no Brasil: contextualização e reflexos sobre o cuidado com o doente mental na família. Rev. Latino-Am. Enfermagem. 2001; 9(2):48-55.

15. Organização Mundial da Saúde (OMS). Relatório sobre a saúde no mundo 2001: saúde mental: nova concepção, nova esperança. Genebra; 2001.
16. Decreto n 44.786 de 23 de março de 2000 (BR). Altera a denominação do Hospital Psiquiátrico de Ribeirão Preto, dispõe sobre sua reorganização e dá providências correlatas. Diário Oficial do Estado, 24 de março, seção I, p. 1-3, 2000.

17. Secretaria do Estado da Saúde (SP). Serviço de atendimento médico especializado do Hospital Santa Tereza de Ribeirão Preto (SAME). Ribeirão Preto; 2009.

18. Amico LC. La institucionalización de la loucura: intervención del trabajo social en alternativas de atención. Buenos Aires: Espaçio Editorial; 2005.

19. Lima MC, Botega NJ. Hospital Dia: para quem e para quê? Rev Bras Psiquiatr. 2001; 23(1):41-50.

20. Furegato ARF. Relações interpessoais terapêuticas na enfermagem. Ribeirão Preto: SCALA; 1999. 